\title{
LULC and NDVI Change Detection in Tarlakota Watershed Project of Srikakulam District, Andhra Pradesh using Remote Sensing and GIS
}

\author{
P. V. R. M. Reddy ${ }^{1 *}$, M. Girija Shankar ${ }^{1}$, B. Janardhan $\operatorname{Reddy}^{1}$, Y. Shankar Naik ${ }^{1}$, \\ R. V. Ramana ${ }^{2}$, D. V.S. R. L. Rekha ${ }^{2}$, N. Kamal Kumar ${ }^{2}$ and M. Singa Rao ${ }^{2}$ \\ ${ }^{1}$ Director (WS), ${ }^{2}$ Commissioner, ${ }^{3}$ Joint Commissioner (WS), ${ }^{4}$ State Technical Expert \\ (Forestry), O/o SLNA, PR\&RD Department, Tadepalli, Andhra Pradesh, India. \\ ${ }^{5}$ Chief Engineer, ${ }^{6}$ Chief, ${ }^{7}$ Deputy Chief Engineer, ${ }^{8}$ Consultant (Soil Science), \\ WAPCOS Limited, Hyderabad, Telangana State, India \\ *Corresponding author
}

\section{A B S T R A C T}

\section{Keywords}

Land Use-Land Cover (LULC),

Normalised

Difference

Vegetation Index

(NDVI), Watershed

Impact (WI),

Remote Sensing

(RS), Geographical

Information System (GIS)

Article Info

Accepted:

20 May 2021

Available Online:

10 June 2021
Government has taken up Integrated Watershed Development Program (IWMP now PMKSY Watershed) to restore the ecological balance by harnessing, conserving and developing degraded natural resources such as soil, vegetative cover and water in degraded rain fed areas of the country. In Tarlakota Project of Palasa Mandal, Srikakulam District, Andhra Pradesh, the watershed program was started during 2012 and completed in 2018). Several NRM and PSI activities were taken up over the five years period (2012 to 2018) in the project area. The present study was taken up to assess the impact of watershed activities taken up in Tarlakota Project on LULC and NDVI using remote sensing and GIS techniques (2011-2012 to 2018-2019). IRS Resourcessat-2 LISS-IV satellite imageries data of 2012 (Pre 11th October, 2012) and 2018 (Post 4th October, 2018) covering the watershed were used to assess the changes in land use/land cover and NDVI over a period of five years. The images were classified into different land use/land cover categories using supervised classification by maximum likelihood algorithm. They were also classified into different vegetation levels using Normalized Difference Vegetation Index (NDVI) approach. Significant changes were observed in LULC over the five years period due to project implementation. The area under crop land and plantation were increased by 322.93 ha $(13.80 \%)$ and 173.32 ha $(19 \%)$ respectively during the project period. This was due to conversion of waste lands and fallow lands into crop lands which may be attributed to better utilization of surface and ground water resources created, adoption of soil and water conservation practices and capacity building of the watershed community. The area under current fallow decreased by 202.20 ha (56.18\%) and waste lands by 368.59 ha $(65.43 \%)$. Substantial increase in the area under dense vegetation 270.95 ha $(21.57 \%)$ and open vegetation 153.10 ha $(8.70 \%)$ was observed. The water body area also increased from 128.83 ha to 157.72 ha which might be due to rain water conservation activities taken up in the project area. 


\section{Introduction}

India is predominantly a rural based agrarian country. Agriculture and allied sectors such as horticulture, livestock, forestry and fisheries together contribute $17.8 \%$ of the country's Gross Value Added (GVA) for the year 201920, (Economic Survey, 2020-21) and provides employment for more than $50 \%$ of the nation's workforce. Thus, it becomes imperative that for the economy of the country to thrive and remain healthy, agriculture must be duly taken care. It also assumes prime importance that since $53 \%$ of net sown area in the country is rain fed, all efforts need to be taken to address the concerns of rain fed areas. Even after realizing the full irrigation potential, about $50 \%$ of the cultivated area in the country will remain rain fed. Despite India ranking first in rain fed agriculture globally in terms of area and production, productivity is among the lowest in the world. Rain fed agriculture is complex and diverse which is highly dependent on rainfall. The rain fed lands suffer from a number of biophysical and socio-economic constraints (Ratna Reddy and Geoffrey, 2015). These include low and erratic rainfall, land degradation and poor productivity, low level of input use and technology adoption, low drought power availability, inadequate fodder availability, low productive livestock, resource poor farmers and inadequate credit availability.

Watershed based approach has become most accepted method for sustainable development of rain fed areas world over. Therefore, Govt. of India has rightly created the National Rain Fed Area Authority (NRAA) as a crucial component of the new watershed policy to address the rain fed area. The watershed is a system based approach that facilitates the holistic development of agriculture and allied activities in the proposed watershed area. It seeks to improve and develop all types of lands - government, forest, community and private lands that fall in a particular watershed. The stress is on improvement of waste land, run off reduction, water conservation and protective irrigation mechanism. As recommended by Parthasarthy Committee (2008), Integrated Watershed Management Programme (IWMP) was started w.e.f. 26.02.2009 for development of rain fed areas combining all other rain fed area development programs. Accordingly, a total of 8,214 projects covering 39.07 million hectares with a total project cost of Rs.50,740 crores have been sanctioned in 28 States (except Goa) during 2009-10 to 2014-15 (GOI, 2018). As per the common guidelines for watershed development projects-2008 (revised edition2011), the period for completing watershed development projects is four to seven years. Based on the regional classification, the treatment costs are Rs.12,000/- or Rs.15,000/per hectare and is shared between the Govt. of India and implementing State. The actual execution of projects from planning to consolidation is undertaken by the States. Subsequent to approval of PMKSY the IWMP was subsumed as one of its components and IWMP is now implemented as WDC-PMKSY w.e.f. 01.07.2015.

The main aim of IWMP is to restore the ecological balance by harnessing, conserving and developing degraded natural resources such as soil, vegetative cover and water. Watershed programs are expected to result in increase of bio-mass, agricultural productivity, increased soil moisture and ground water recharge. All these positively influence vegetative cover. Watershed programs also change the land use and land cover. The changes in land use/land cover are considered as a measure to analyse the impact of the watershed program. Changes in land use/land cover also plays an important role in the global environment change process (Patel et al., 2013). The Normalized Difference Vegetation Index (NDVI) provides a robust 
index of productivity as it measures chlorophyll content on scale from -1 to +1 and this index has been used extensively for land cover mapping. This method has been used extensively across the world. The NDVI have deduced values corresponding to dense vegetation, open vegetation, degraded vegetation, fallow land and water bodies.

In Andhra Pradesh the program is being implemented by State Level Nodal Agency (SLNA) under PR \&RD Department. A total of 373 projects are being taken up in the State in five batches in all the districts except Krishna District. In Srikakulam District, a total of 18 projects in five batches are being implemented. The present study pertains to Tarlakota Project which was completed during the year 2018 under Batch-III (2011-12). The aim of the study was to know the changes in land use/land cover and NDVI due to implementation of watershed programs from 2012 to 2018 using remote sensing and GIS.

The satellite remote sensing provides an excellent source of data from which updated land use/land cover changes can be extracted in an efficient way. This is the most effective method which has been adapted by many researchers, Thakkar, et al., 2017), Bhandari, et al., 2012), Nagaveni, et al., 2017). Remote Sensing (RS) and Geographical Information System (GIS) has been proved as an effective tool to monitor and manage the natural resources and assess the impact and watershed during pre and post development. This involves development of spatial and temporal database and analysis technique. In Tarlakota, several natural resources (soil and water conservation) and Production Systems Improvement (PSI) activities were taken up during the project period. These programs are likely to increase the area under cultivation, decrease area in wasteland, conversion of annual crop land to horticulture, change in water body area and bio-mass.

\section{Study Area}

Srikakulam District is in extreme Northern district of Andhra Pradesh bordering Odisha in the North and Bay of Bengal in the East. The annual rainfall of the district is around 1160 $\mathrm{mm}$. The cultivated area in the district is about $60 \%$ of the geographical area. Nearly $84 \%$ of the people in the district live in rural areas.

The present study pertains to Tarlakota Watershed which is part of Palasa Mandal in DPAP Block of Srikakulam District. The watershed is located between North Latitude $18^{\circ} 22^{\prime} 46^{\prime \prime}$ and 18 $16^{\circ} 19^{\prime \prime}$ and Eastern Longitude $84^{\circ} 33^{\prime} 19^{\prime \prime}$ and $84^{\circ} 30^{\prime} 24^{\prime \prime}$. It is at a distance of $104 \mathrm{kms}$ from the district headquarters and is located at an elevation of $2.10 \mathrm{~m}$ above the MSL. Highest point in the watershed is $5.5 \mathrm{~m}$ above the MSL at ridge. The total geographical area of the watershed is 5777.15 hectares and net treatable area is 3591.00 ha. The average annual rainfall (10 years) in the area is $1285.72 \mathrm{~mm}$. Most of the soils are red sandy to red sandy loam with low water retention capacity and poor fertility.

The temperatures in the area are in the range between $39.29^{\circ} \mathrm{C}$ during summer and $21.19^{\circ} \mathrm{C}$ during winter. There are 25 number of habitations spread over in eight micro watersheds. The main occupation of the watershed community is agriculture, mostly under rain fed cultivation which is vulnerable to drought, failure of monsoons and also affected by cyclones as well.

\section{Materials and Methods}

To know the changes in land use and land cover (LULC and NDVI), due to implementation of watershed program, remote sensing technique is adopted following pre and post project period data analysis by using IRS Resourcessat-2 LISS-IV satellite imageries for the years 2012 (Pre - 11th 
October, 2012) and 2018 (Post - 4th October, 2018) on cloud free days. The methodology adopted is given below:

Satellite imageries for pre and post project period are procured for the year 2012 and 2018.

Topographical sheets are procured from Survey of India (SOI) for reference maps.

For change detection analysis two working methodologies are adopted:

To measure the changes in vegetation cover supervised classification (maximum likelihood classification) was conducted.

Normalized Difference Vegetation Index (NDVI) was carried out to identify the difference between NDVI values for the years 2012 and 2018.

Land Use/Land Cover categories like crop land, fallow land, plantation, forest, degraded lands etc. classes are arrived at using supervised classification method.

NDVI range of index values for different class categories like, dense vegetation, open vegetation and degraded vegetation are prepared.

Results of both methods are studied and analysed for assessing the changes occurred due to implementation of the watershed programme.

\section{Land Use and Land Cover (LULC)}

Remote sensing based image processing method of supervised classification technique is used to extract land use classes like crop land, fallow land, plantation, forest, degraded lands etc. from the IRS Resourcessat-2 LISSIV satellite imagery. The land use-land cover class wise statistical values are compared in order to evaluate the changes in the period of time from year 2012 to 2018 .

\section{Normalized Difference Vegetation Index (NDVI)}

Normalized Difference Vegetation Index (NDVI) is calculated in accordance with the formula:

Where

$\mathrm{NDVI}=(\mathrm{NIR}-\mathrm{RED}) /(\mathrm{NIR}+\mathrm{RED})$

NIR - reflection in the near-infrared spectrum RED - reflection in the red range of the spectrum

NDVI is a measure of the state of plant health based on how the plant reflects light at certain frequencies. The NDVI Index defines values from -1.0 to +1.0 basically representing greenness. Chlorophyll (a health indicator) strongly absorbs visible light, and the cellular structure of the leaves strongly reflect nearinfrared light.

Using the range of index values for different categories like dense vegetation, open vegetation and degraded vegetation are compared and analysed for the pre- and postperiods for the study area. NDVI measured on the fly-in-change detection monitoring of green vegetation for the period of time (Years 2012 and 2018) in the study.

\section{Consequence of the methodology}

Statistical results of pre and post-values generated from the above methods are compared with the field investigation data. The results are used to analyse the changes taken place during the project period for studying the impact of the watershed programme. 


\section{Results and Discussion}

\section{Changes in Land Use / Land Cover from 2012 to 2018}

Spatial distribution statistics of Tarlakota Project area under different land use/land cover categories for both pre and post-project periods are shown in Fig.-1 and Table-1.

The data indicate lot of change in land use/land cover distribution during the project period. Significant increase in area under cropland and plantations are observed, which is due to promoting agriculture and horticulture crops. Under cropland there was an area of 2339.75 ha during 2012 and 2662.68 ha in 2018, indicating an increase of 322.93 ha which is $13.80 \%$ increase during the project period. The current fallow which was 359.92 ha during 2012 decreased to 157.72 ha in 2018 indicating conversion of 202.20 ha fallow land into crop land due to implementation of watershed program. It is interesting to note that there was decrease in waste land/scrub land from 664.95 ha to 296.36 ha from pre-project (2012) to postproject (2018) period amounting to 368.59 ha. Garima Sharma and Sharma (2020) reported significant reduction in the waste land i.e. land with shrubs and land without shrubs decreased due to implementation of Integrated Watershed Management Program in Bassi Block in Jaipur District, Rajasthan. Biswajit Mondal et al., (2018) studied the impact of watershed program in eight watersheds operated by Govt. and NGOs and reported increased gross cropped area ranging between $20 \%$ and $78 \%$ in the watershed areas. They also reported that the area under waste lands/permanent fallow decreased by $50 \%$ and similar increase in area under pasture land and forest area in eight watersheds programs taken up in Bundelkhand region of Madhya Pradesh State. They attributed this to improvement in land quality of waste land after the implementation of the IWMP in the study area which was brought under cultivation.

The increase in crop land in the present study was due to capacity building activities taken up by the Department of Agriculture in the form of crop technology demonstrations, training programs etc. there by the farmer became aware of the improved technologies and started cultivating the lands which were left fallow prior to the project. Several rain water conservation activities (Table No.2) like check dams, percolation tank, farm ponds etc. were taken up in the project area which helped in providing irrigation to the crops by use of surface water and also ground water.

Painuli, et al., (2018) made impact evaluation of 30 micro watersheds in Jailsalmer District of Rajasthan and reported an average increase in area under agriculture from 882.24 ha to 917.76 ha due to implementation of watershed program. They attributed the increase in crop land area to reclaiming effect of various measures taken through watershed activities.

Researchers in their finding have argued that more focused management intervention requires information on the rates and impacts of LULC change as well as the distribution of these changes in space and time as a central component in present strategies for managing natural resource and monitoring environmental changes. Land use/cover change can affect biodiversity, biogeochemical cycles, soil fertility, hydrological cycles, energy balance, land productivity and the sustainability of environmental services. In most parts of the world, agriculture is the primary driver of land use change. But few comprehensive studies have been undertaken at a global level on long-term historical changes of land cover due to land use practice. 
Table.1 Changes in Land Use/Land Cover from 2012 to 2018 in Tarlakota Project

\begin{tabular}{|c|c|c|c|c|c|}
\hline SI.No. & LULC Category & Pre Project & Post Project & Diff. & Diff. in \% \\
\hline & & \multicolumn{2}{|c|}{ Area in Ha. } & & \\
\hline $\mathbf{1}$ & $\mathbf{2}$ & $\mathbf{3}$ & $\mathbf{4}$ & $\mathbf{5}(\mathbf{4 - 3})$ & $\mathbf{6}(\mathbf{5 / 3})$ \\
\hline $\mathbf{1}$ & Built-up & 291.17 & 320.05 & 28.88 & $\mathbf{9 . 9 2}$ \\
\hline $\mathbf{2}$ & Cropland & 2339.75 & 2662.68 & 322.93 & $\mathbf{1 3 . 8 0}$ \\
\hline $\mathbf{3}$ & Plantation & 912.21 & 1085.53 & 173.32 & $\mathbf{1 9 . 0 0}$ \\
\hline $\mathbf{4}$ & Current Fallow & 359.92 & 157.72 & -202.20 & $\mathbf{- 5 6 . 1 8}$ \\
\hline $\mathbf{5}$ & Forest & 882.17 & 894.31 & 12.14 & $\mathbf{1 . 3 8}$ \\
\hline $\mathbf{6}$ & Wasteland / Scrubland & 664.95 & 296.36 & -368.59 & $\mathbf{- 5 5 . 4 3}$ \\
\hline $\mathbf{7}$ & River/Water bodies & 128.83 & 157.72 & 28.89 & $\mathbf{2 2 . 4 2}$ \\
\hline $\mathbf{8}$ & Quarry Area & 198.16 & 202.78 & 4.62 & $\mathbf{2 . 3 3}$ \\
\hline & Total & $\mathbf{5 7 7 7 . 1 6}$ & $\mathbf{5 7 7 7 . 1 6}$ & & \\
\hline
\end{tabular}

Table.2 Rain Water Conservation works taken up in the Project

\begin{tabular}{|c|c|c|}
\hline Sl. No. & NRM works taken up & No. of works \\
\hline $\mathbf{1}$ & Check Dams & $\mathbf{1 4}$ \\
\hline $\mathbf{2}$ & Farm Ponds & $\mathbf{4 9}$ \\
\hline $\mathbf{3}$ & Percolation Tank & $\mathbf{2 1}$ \\
\hline $\mathbf{4}$ & Mini Percolation Tank & $\mathbf{0 2}$ \\
\hline $\mathbf{5}$ & Repairs to existing percolation tank & $\mathbf{1 0}$ \\
\hline $\mathbf{6}$ & Repairs to existing check dam & $\mathbf{0 9}$ \\
\hline $\mathbf{7}$ & Repairs to existing mini percolation tank & $\mathbf{0 1}$ \\
\hline $\mathbf{8}$ & Loose Boulder Structure & $\mathbf{6 9}$ \\
\hline $\mathbf{9}$ & Staggered Trenches & $\mathbf{2 1 4}$ \\
\hline $\mathbf{1 0}$ & Water absorption trench at foot hills & $\mathbf{0 1}$ \\
\hline $\mathbf{1 1}$ & Digging of peripheral trenches & $\mathbf{0 5}$ \\
\hline $\mathbf{1 2}$ & Recharge pits & $\mathbf{1 0}$ \\
\hline
\end{tabular}

Table.3 Plantation works taken up in the project area

\begin{tabular}{|c|c|c|}
\hline Sl. No. & Plantation works taken up & No. of works \\
\hline $\mathbf{1}$ & Block Plantation in Private Lands & $\mathbf{2 9 6}$ \\
\hline $\mathbf{2}$ & Raising of Horticulture Plantation - Mango & $\mathbf{3 0 2}$ \\
\hline $\mathbf{3}$ & Raising of Horticulture Plantation - Cashew & $\mathbf{1 7}$ \\
\hline $\mathbf{4}$ & Avenue Plantations & $\mathbf{0 3}$ \\
\hline
\end{tabular}


Fig.1 The methodology adopted is presented in the flow chart

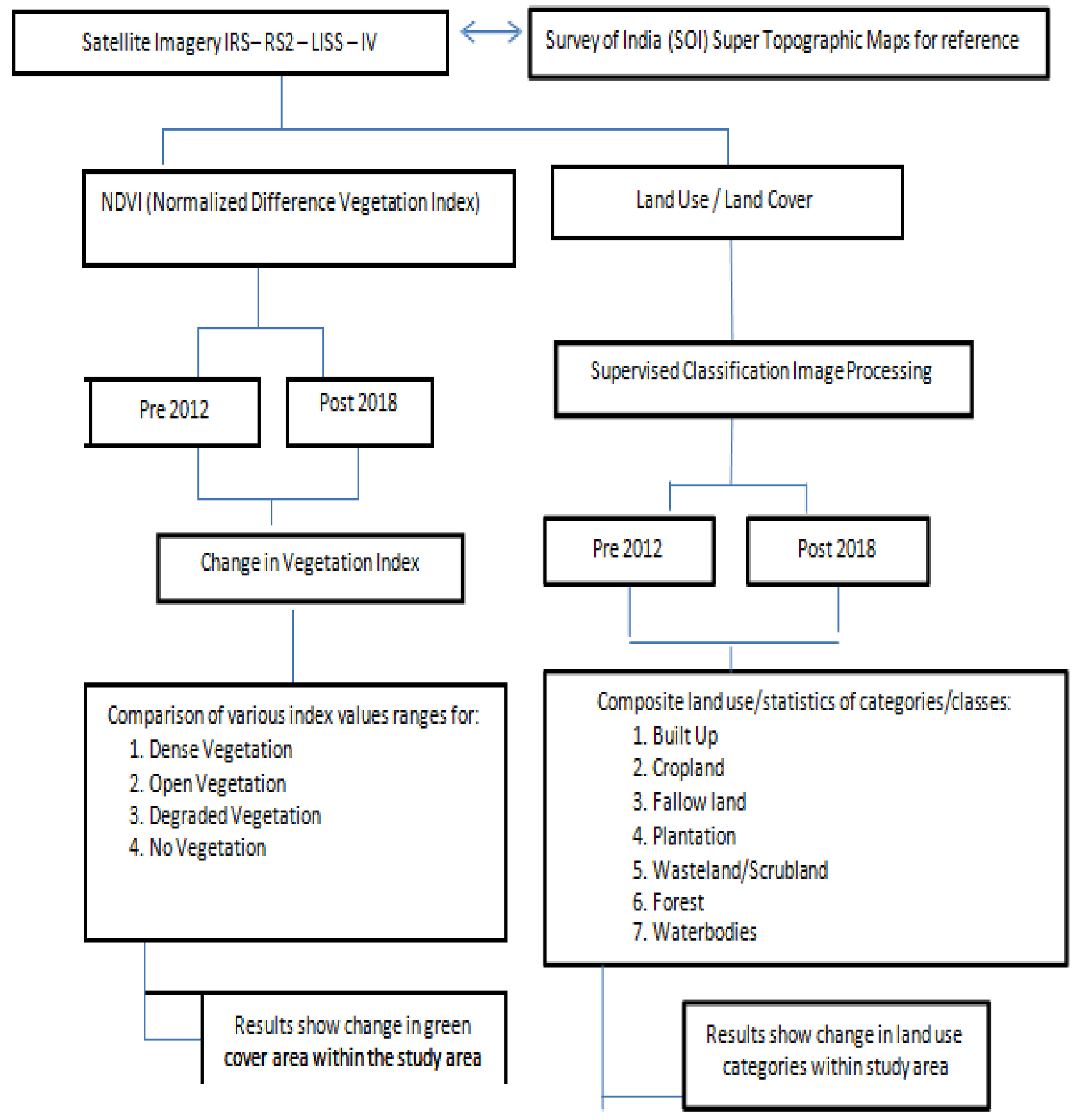


Table.4 Changes in NDVI during 2012 and 2018 in Tarlakota Project

\begin{tabular}{|c|c|c|c|c|c|}
\hline Sl. No. & LULC Category & Pre Project & \multicolumn{1}{c|}{ Post Project } & Diff. & Diff. in \% \\
\hline $\mathbf{1}$ & $\mathbf{2}$ & $\mathbf{3}$ & $\mathbf{4}$ & $\mathbf{5}(\mathbf{4 - 3})$ & $\mathbf{6}(\mathbf{5} / \mathbf{3})$ \\
\hline $\mathbf{1}$ & Dense vegetation & 1255.95 & 1526.90 & 270.95 & $\mathbf{2 1 . 5 7}$ \\
\hline $\mathbf{2}$ & Open vegetation & 1759.72 & 1912.82 & 153.10 & $\mathbf{8 . 7 0}$ \\
\hline $\mathbf{3}$ & Degraded vegetation & 1385.36 & 1061.26 & -324.10 & $\mathbf{- 2 3 . 3 9}$ \\
\hline $\mathbf{4}$ & Fallow/ No vegetation & 956.12 & 798.39 & -157.73 & $\mathbf{- 1 6 . 5 0}$ \\
\hline $\mathbf{5}$ & Built-up & 291.17 & 320.05 & 28.88 & $\mathbf{9 . 9 2}$ \\
\hline $\mathbf{6}$ & Water Bodies & 128.83 & 157.72 & 28.89 & $\mathbf{2 2 . 4 2}$ \\
\hline & Total & $\mathbf{5 7 7 7 . 1 5}$ & $\mathbf{5 7 7 7 . 1 5}$ & & \\
\hline
\end{tabular}

Fig.2 Changes in Land Use/Land Cover from 2012 to 2018 in Tarlakota Project

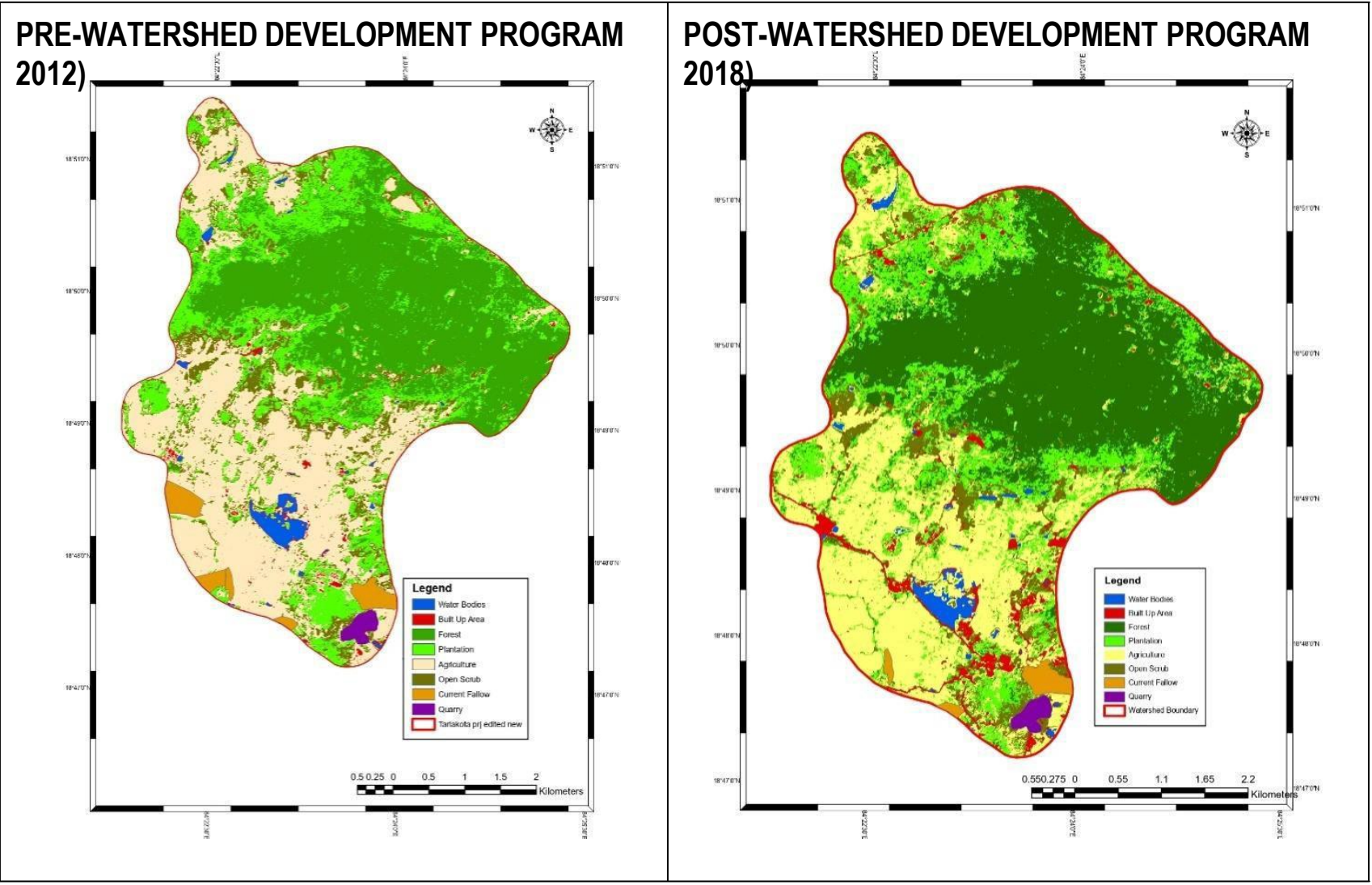


Fig.3 Changes in NDVI during 2012 and 2018 in Tarlakota Project

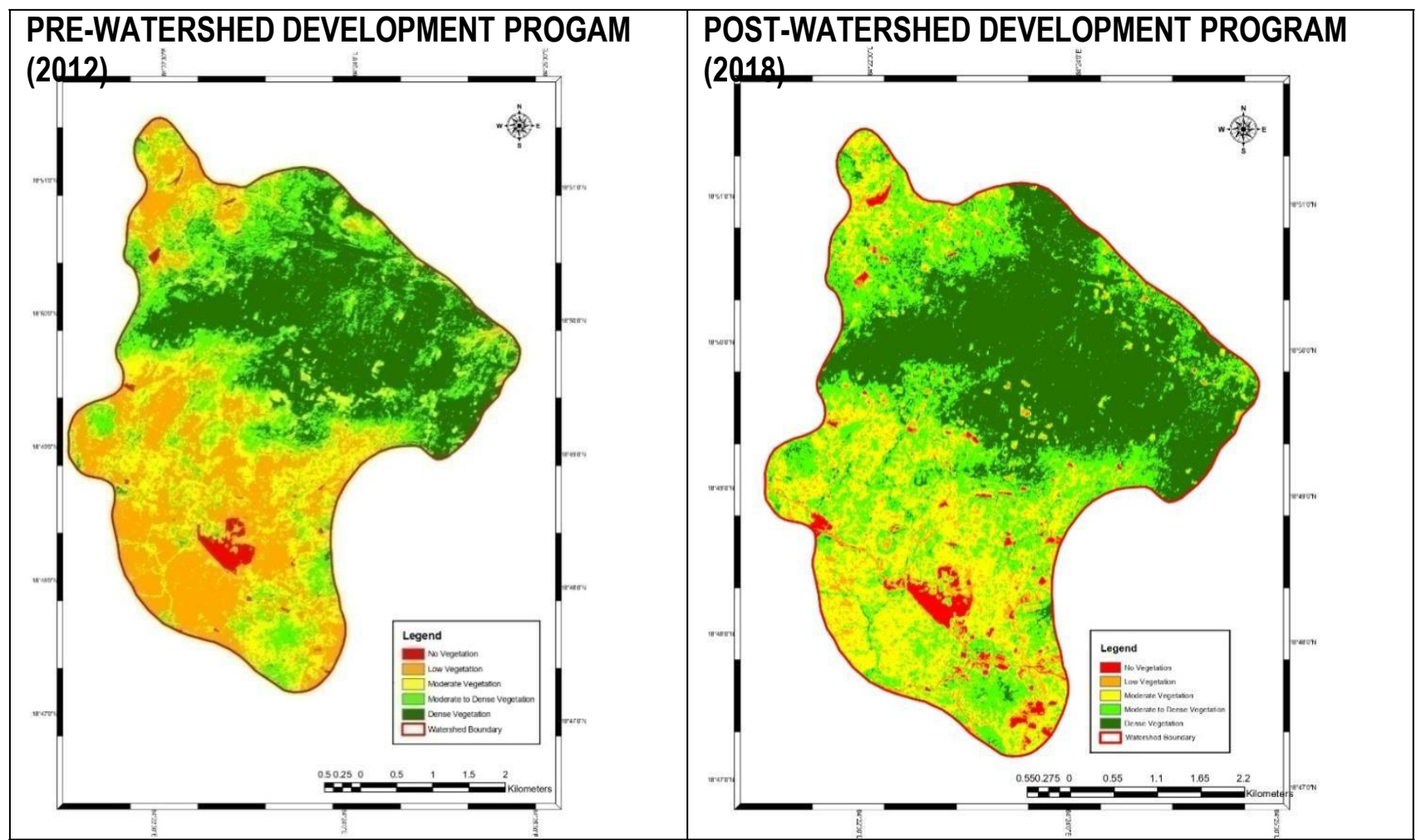

Fig.4 Changes in Water Body Area in Tarlakota Project from 2012 To 2018

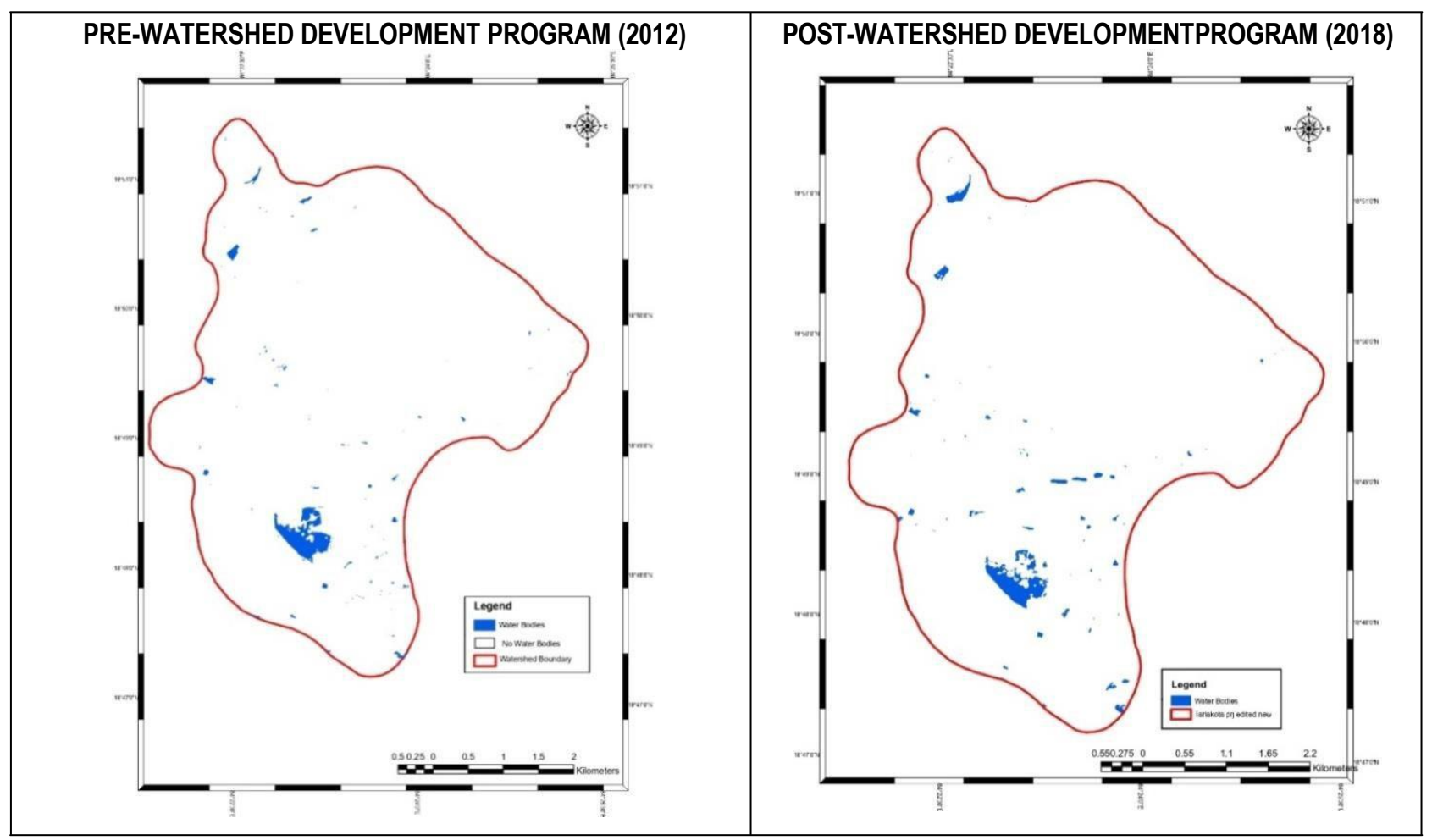


However, land cover change has recently become a major concern for research on global warming and global change; it draws attention and has emerged as a research agenda for many researchers.

The area under plantations increased by 173.22 ha (Table-1) during the project period from 912.21 ha (2012) to 1085.53 ha (2018). This was mainly due to the block plantation in private lands, mango and cashew plantations (Table 3) taken up in farmer's fields during the project period.

\section{Changes in NDVI}

The Normalized Difference Vegetation Index (NDVI) maps were generated for Tarlakota Project, pre project (2012) and post project (2018). They were classified into different vegetation vigour classes like dense, open, degraded and fallow. The statistics are presented in Fig.2 and Table 4. It is clear from the data that there is increase in dense and open vegetation and decrease in degraded vegetation and fallow. The increase in dense vegetation was from 1255.95 ha to 1526.90 ha (an increase of $21.57 \%$ ) and that of open vegetation from 1759.72 ha to 1912.82 ha with (an increase of $8.70 \%$ ) during the project period from 2012 to 2018. The increase may be due to conversion of degraded vegetation area and no vegetation area into dense vegetation and open vegetation. It may be observed from (Table 3) that during the project period large number of block plantation (296 Nos.) were taken up in private lands. Similarly, considerable number of horticulture plantations (Cashew -17 Nos. and Mango - 302 Nos.) were also taken up in the area. Apart from these avenue plantations (03 Nos.) were taken up at three places on the road sides. All these activities were responsible for increase in dense vegetation in the project area. The rain water conservation activities taken up in the project period helped to increase the area under irrigation (19.75\%). Similarly, lot of greenery was created around the water bodies like check dams, percolation tank, farm ponds etc. which also reflected in increase of open vegetation.

\section{Changes in Water body Area}

Changes in water body area is a good indicator of rain water harvesting activities taken up in the project area. Water body area in Tarlakota watershed is extracted by using LISS-IV satellite data for the years 2012 and 2018. The increase in the water body area was from 128.83 ha to 157.72 ha, an increase of 28.89 ha. This is due to the construction of large number of rain water harvesting structures (Table 2) like farm ponds, percolation tanks, check dam etc. during the project period.

Amee K. Thakkar, et al., (2017) while studying the impact of Watershed Management Program and Land Use/Land Cover dynamics in Khan-Kali watershed and Anas River from Gujarat reported 20\% to 50\% increase in water body area due to implementation of watershed programs and concluded that the watershed management programs showed overall positive impact in the study area.

Land Use/Land Cover and NDVI change studies have been carried out in Tarlakota Watershed Project in Srikakulam District from 2012 to 2018. It is observed that significant changes in land use/land cover and NDVI occurred due to watershed program. The crop land increased from 2339.75 ha to 2662.68 ha from 2012 to 2018. Similarly, the area under plantation also increased by 322.93 ha during the project period. It can be noted that crop land area has increased due to conversion of current fallow land and waste land into crop land. The output of NDVI classification indicates increase in dense vegetation from 1255.95 ha to 1526.90 ha due to the watershed 
developmental activities. NDVI studies indicated that there is considerable improvement in dense and open vegetation categories due to watershed programs during 2012 and 2018. There was increase in water bodies area of 28.89 ha due to rain water conservation activities like check dams, farm ponds, percolation tanks etc.

\section{References}

Amee K. Thakkar, Venkappayya R Desai, Ajay Patel and Madhukar B. Potdar, (2017). Impact assessment of watershed management program on land use/land cover dynamics using remote sensing and GIS. Remote Sensing Applications: Society and Environment 5. pp.1-15.

Bhandari A. K, Kumar A and Singh G. K., (2012). Feature extraction using normalized difference vegetation index (NDVI): A case study of Jabalpur City, Procedia Technology 6. pp.612-621.

Biswajit Mondal, Alka Singh, S. D Singh, B. S. Kalra, P. Samal, M. K. Sinha, D. Ramajayam and Suresh Kumar, (2018). Augmentation of water resources potential and cropping intensification through watershed programs. Water Environment Research, January, 2018. pp. 83-91.

GOI, (2008). Common guidelines for planning and implementation of watershed development program in India.

GOI, (2021). Economic Survey 2020-21, Ministry of Finance, Govt. of India.

GOI, (2018). 49th Report of standing committee on Rural Development for 2017-2018 submitted to Lok Sabha), Ministry of Rural Development (Department of Land
Resources).

Nagaveni C and Venkata Ravibabu M, (2017). Impact assessment of watershed management on land use/land cover change using RS and GIS: A case study, International Journal of Civil Engineering and Technology, Vol.8, pp. 394-400.

Painuli D. K., R. K. Goyal, Bhagwan Singh, Rajwant Kaur Kalia, M. M. Roy, (2014). Impact evaluation of watershed programs in Jaisalmer District of Rajasthan, Central Arid Zone Research Institute, Jodhpur, India, (Report).

Patel D. P., Gajjar C. A., Srivastava P. K., (2013). Prioritization of malesari mini watersheds through morpho metric analysis: A remote sensing and GIS perspective. Environ. Earth Science, 69. pp. 2643-2656.

Ratna Reddy V and Geoffrey J. Syme, (2015). Integrated assessment of scale impacts of watershed intervention assessing hydrogeological and bio-physical influences on livelihoods, Elsevier Inc. Publication.

Sharma G and R. N. Sharma, (2020). Application of GIS and remote sensing for the impact assessment of integrated watershed management program: A case study of bassi block, Jaipur District, International Journal of Scientific \& Technology Research. Vol. 9, issue 01, pp. 983-989.

Thakkar A. K, Desai V. R., Patel A. and Potdar M. B., (2017). Application of remote sensing in analysis of impact assessment using bio-mass vigour changes of watersheds, Journal of Environmental Biology. Vol.38, pp. 543-551.

\section{How to cite this article:}

Reddy, P. V. R. M., M. Girija Shankar, B. Janardhan Reddy, Y. Shankar Naik, R. V. Ramana, D. V. S. R. L. Rekha, N. Kamal Kumar and Singa Rao, M. 2021. LULC and NDVI Change Detection in Tarlakota Watershed Project of Srikakulam District, Andhra Pradesh using Remote Sensing and GIS. Int.J.Curr.Microbiol.App.Sci. 10(06): 818-828. doi: https://doi.org/10.20546/ijcmas.2021.1006.087 